- Entomologica Fennica. 15 October 1999

\title{
A new sawfly species Caliroa crypta sp. nov. from Northern Europe (Hymenoptera, Tenthredinidae)
}

\author{
Mikk Heidemaa
}

\begin{abstract}
A new tenthredinid species Caliroa crypta sp. nov. is described on the basis of one female from Estonia and one male from Finland. The new species slightly resembles $C$. tremulae Chevin but the sculpture of its abdominal terga is alutaceous-coriaceous like that in Endelomyia aethiops (Fabricius). The host plant and larva of the species are unknown. - Entomologica Fennica 10: 183-186.

Department of Applied Zoology, University of Helsinki, P.O. Box 27, FIN-00014 Helsinki, Finland

Institute of Zoology and Hydrobiology, University of Tartu, Vanemuise 46, 51014 Tartu, Estonia

For correspondence: Institute of Plant Protection, Estonian Agricultural University, Viljandi Road, Eerika, 50412 Tartu, Estonia
\end{abstract}

Received 17 April 1998, accepted 26 May 1999

\section{Introduction}

Five species of the Holarctic sawfly genus Caliroa A. Costa have been reported from Europe (Chevin 1974, Liston 1995). To date four of those, excluding Caliroa varipes (Klug, 1816), have been recorded from Finland (Viitasaari 1981, Viitasaari \& Vikberg 1985).

During a collecting excursion in the park of the Palmse estate, Lahemaa National Park, Northern Estonia, on 18 July 1993 I caught an interesting Caliroa female by sweeping. I could not identify it using the published keys for that genus because it showed some unique characters that differentiated it from all other Caliroa species recorded from Europe. This specimen was referred to as Caliroa sp. in the annotated checklist of the sawflies of Estonia (Viitasaari et al. 1998). After some years, when I had an opportunity to examine the large material of Caliroa deposited in the institutional and private collections in Helsinki, I found one male that showed very similar characters and was therefore considered conspecific with the above-mentioned female collected in Estonia. These two specimens share some unique characters that clearly differentiate them from all other related species that have been described to date from Europe.

\section{Caliroa crypta sp. nov.}

Figs. 1, 2, 3, 4a, 4b, 5

cryptus (Gr.) - absconditus (Lat.) - hidden, shaded, cryptic.

Type material. Holotype o in coll. Dept. of Applied Zoology, University of Helsinki; labelled: "Estonia Palmse MF49 [UTM grid reference] 17.07.1993 M.Heidemaa leg." [printed, white label]; "in the park of the Palmse estate, by sweeping on the bushes and grass" [printed, white label]; "HOLOTYPUS 1999 CALIROA CRYPTA SP. NOV. G des. M. Heidemaa" [red label].

Paratype $\sigma^{\star}$ in coll. Matti Viitasaari; labelled: "Suomi [Finland] V Perniö 2.7.1948 P. Niemelä leg." [printed (date is handwritten), white label with a black frame]; "PARATYPUS 1999 CALIROA CRYPTA SP. NOV. o des. M. Heidemaa" [red label].

Holotype. 9 . Length of fore wing $4.0 \mathrm{~mm}$, of 


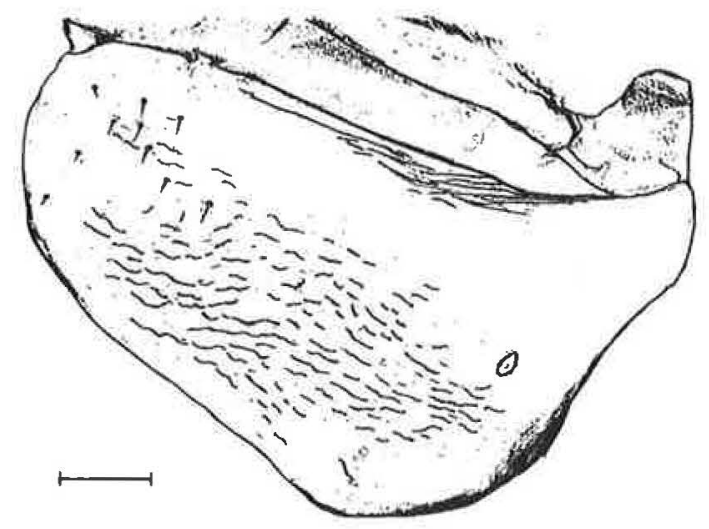

Fig. 1. Caliroa crypta sp. nov., holotype $\odot$. Alutaceouscoriaceos sculpture on tergum 1. Scale line $0.1 \mathrm{~mm}$.

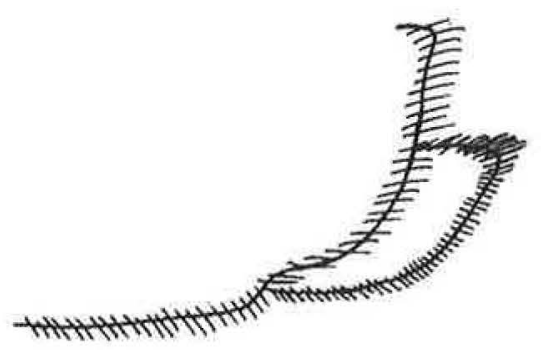

Fig. 2. Caliroa crypta sp. nov., holotype 9 . Ovipositor sheath in lateral view. Scale line $0.1 \mathrm{~mm}$.

body about $4.2 \mathrm{~mm}$. Colour black; mandible apically reddish; hairs on head dark, on thorax paler; apical tips of femora with narrow brownish ring, pro- and mesotibiae and tarsi, basal 0.4-0.5 of metatibia, apical tips of femora, and hind tarsomeres 1, 2 whitish. Spurs of pro- and mesotibiae pale, of metatibiae black. Labrum blackish with irregular sculpture. Wings uniformly, slightly infuscated. Temples with rough punctures. The sculptured groove behind the compound eye distinct. Antenna with flagellomere 1 subequal in length to flagellomeres $2+3$. Length of the flagellomeres 1-3: 1.-0.49 mm, 2.-0.31 mm, 3.-0.26 $\mathrm{mm}$. Combined length of flagellomeres 4-7 longer than that of flagellomeres $2+3$. Metatarsus slightly longer than metatibia. Clypeus subemarginated. Fore wing with vein $\mathbf{M}$ strongly curved near its base; vein $2 r$ joins vein SR at about apical 0.27 part of cell 2 SR. Hind wing with cells Rs

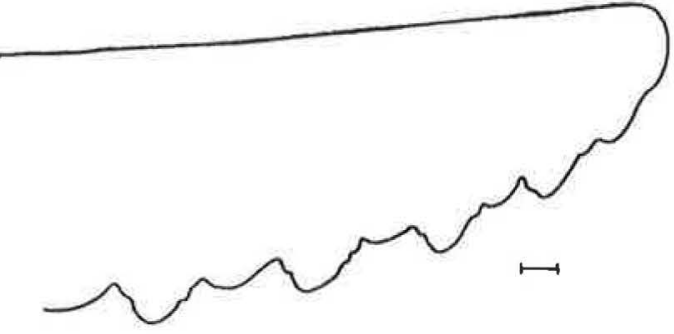

Fig. 3. Caliroa crypta sp. nov., holotype + . Contour of the apical sawteeth. Scale line $0.01 \mathrm{~mm}$.

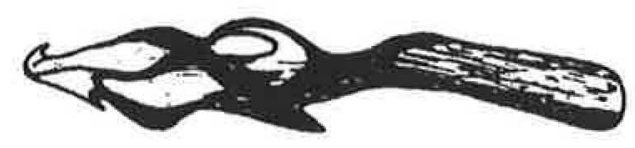

a

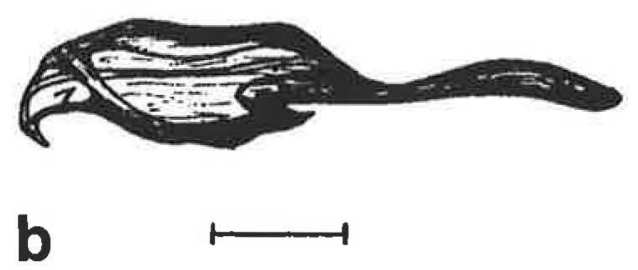

Fig. 4. Caliroa crypta sp. nov., paratype ơ. Penis valve. a: dorsal view. - b: lateral view. Scale line $0.1 \mathrm{~mm}$.

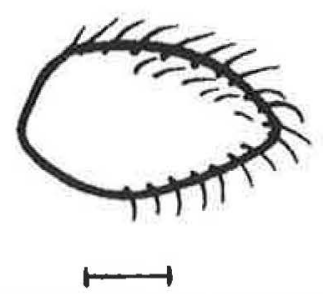

Fig. 5. Caliroa crypta sp. nov., paratype ${ }^{*}$. Harpe. Scale line $0.1 \mathrm{~mm}$.

and $\mathrm{M}$ absent; anal cell with short petiole (about as long as pedicel). Mesoscutellar appendage shining with irregular pitlike depressions. Distance between cenchri about 1.5 as wide as maximal diameter of a cenchrus. Terga alutaceous-coriaceous (Fig. 1). Ovipositor sheath in lateral view as in Fig. 2. Sawteeth rounded-triangular, slightly pointed at apex, and without distinct denticles (Fig. 3.) (lancet was not dissected, the apical sawteeth are visible). 
Paratype. $\sigma^{*}$. Length of fore wing $3.4 \mathrm{~mm}$, of body about $3.7 \mathrm{~mm}$. Colour black; mandible apically reddish; hairs brownish; legs blackish with pro- and mesotibiae, tarsi and apical half of femora whitish. Hind legs with metatibia at base with narrow whitish ring and darkening gradually towards apex, apically blackish. Posterior aspect of metatibia paler than anterior and outer aspects. Metatarsomeres apically blackish, gradually turning pale towards base. Labrum brownish with irregular sculpture. Wings uniformly, slightly infuscated. Temples with rough puncture. The sculptured groove behind the compound eye distinct. Antenna with flagellomere 1 subequal in length to flagellomeres $2+3$. Length of the flagellomeres 1-3: $1 .-0.42 \mathrm{~mm}, 2 .-0.25 \mathrm{~mm}, 3 .-0.23 \mathrm{~mm}$. Combined length of flagellomeres 4-7 longer than that of flagellomeres $2+3$. Metatarsus slightly longer than metatibia. Clypeus subemarginated. Fore wing with vein $\mathrm{M}$ less strongly curved near its base than in female; vein $2 r$ joins vein $S R$ at about apical 0.40 part of cell 2 SR. Hind wing with marginal vein, with cells $M$ and Rs absent; apex of anal cell removed some distance from margin of wing. Mesoscutellar appendage shining with irregular pitlike depressions. Sculpture of terga is very similar to that in female. Penis valve in dorsal and lateral view as in the Figs. 4a, 4b. Harpe as in Fig. 5.

\section{Discussion}

Compared with other European species of Caliroa, the new species shows some resemblance with C. tremulae Chevin but it is smaller. It has a petiolate anal cell in the hind wing, the temples are less shining, with punctures, and the sculptured groove behind the compound eye is distinct. The mesopleuron is smooth and shining with sparse but clear punctures on its surface (resembling C. cerasi). The punctures are also more robust on the pronotum, mesonotum, and frontal area. The sculpture of the abdominal terga is alutaceouscoriaceous (Eady 1968) resembling Endelomyia aethiops while other European species of Caliroa have the terga smooth and shining (C. tremulae sometimes show slightly pustulate sculpture of the terga). According to the original descrip- tion in Zombory (1977), the female of Caliroa carinata from Korea shows similar sculpture of the terga. Like in C. tremulae, these two specimens have a chain of small pits separating the scutellum and mesoscutellar appendage. The epicnemium is uniform in width and seems more distinct because of the sculptured epicnemial groove. The specimens were compared with descriptions of the following Caliroa species from Eastern Palaearctic: C. angustata Forsius, 1927, C. negativa Malaise, 1931, C. carinata Zombori, 1977, C. evodiae Xiao, 1993, and C. toonae Li \& Guo, 1995. The key for Nearctic Caliroa in Smith (1971), and those by Okutani (1965), Togashi \& Oishi (1978), Wei (1997), and Vasu (1998) for the Oriental Caliroa species were checked as well. They were also compared with the description of Caliroa algeriensis in Lacourt (1998). However, the characters of these specimens did not agree with those given for the above-mentioned species. Because of several distinct and unique characters, these specimens were considered to represent an undescribed species of Caliroa that might have eastern (Siberian) distribution.

Acknowledgements. I am grateful to Matti Viitasaari for his kind help and giving access to his private collection. Anders Albrecht enabled the examination of related material at the Zoological Museum of Helsinki. Alexey Zinovjev checked the Caliroa material at the Zoological Institute in St. Petersburg. Matti Nuorteva and Jouko Nuorteva kindly let me examine their Caliroa material. David Smith and Veli Vikberg helped with terminology and revised the manuscript. I thank also the staff of the Department of Applied Zoology for their kind help during my visit. Margot Stout Whiting checked the English.

\section{References}

Chevin, H. 1974: Contribution à l'etude systématique et biologique du genere Caliroa et description d'une espèce nouvelle (Hym. Tenthredinidae). - Bulletin de la Société entomologique de France. 79: 158-165.

Eady, R.D. 1968: Some illustrations of microsculpture in the Hymenoptera. - Proceedings of the Royal Entomological Society of London (A) 43: 66-72.

Forsius, R. 1927: Tenthredinoiden aus China eingesammelt von Herrn Dir. Kj. Kolthoff 1921. - Arkiv för Zoologi. 19 A, 10: 1-12.

Lacourt, J. 1998: Description d'une nouvelle espèce de Caliroa d'Algerie (Hym., Tenthredinidae). - Bulletin de la Société entomologique de France, 103(4): 393-394. 
Li, M.-1. \& Guo, X.-r. 1995: A new species of the genus Caliroa from China (Hymenoptera: Tenthredinidae). Journal of Northwest Forestry College. 10, 2: 98-100.

Liston, A. D. 1995: Compendium of European sawflies. Chalastos Forestry, Gottfrieding. $190 \mathrm{pp}$.

Malaise, R. 1931: Blattwespen aus Wladiwostok und anderen Teilen Ostasiens. - Entomologisk Tidskrift. 51, 2: 97-159.

Okutani, T. 1965: The Japanese sawflies of the genus Caliroa, with description of its larval character. - Japanese Journal of Applied Entomology and Zoology. 9: 29-33.

Smith, D. R. 1971: Nearctic sawflies III. Heterarthrinae: Adults and Larvae (Hymenoptera: Tenthredinidae). Technical Bulletin. United States Department of Agriculture, No. 1420, 84+XVIII pp.

Togashi, I., Oishi T. 1978: A New Plum-slug Sawfly, Caliroa sumomovora (Hymenoptera, Tenthredinidae), Injurious to Oishi-Plum in Japan. - Kontyû. 46, 1: 20-23.

Vasu, V. 1998: First records and new species of Caliroa Costa (Hymenoptera: Tenthredinidae: Heterarthrinae) from
India. - Entomotaxonomia. 20, 4: 285-290.

Viitasaari, M. 1981: The genus Caliroa (Hymenoptera, Tenthredinidae) in Finland. - Notulae Entomol. 61: 197200.

Viitasaari, M. \& Vikberg, V. 1985: A checklist of the sawflies (Hymenoptera, Symphyta) of Finland. - Notulae Entomol. 65: 1-17.

Viitasaari, M., Heidemaa, M., Nuorteva, M., Zinovjev, A. 1998: An annotated checklist of the sawflies (Hymenoptera, Symphyta) of Estonia. - Proc. Estonian Acad. Sci. Biol. Ecol. 47, 2: 126-147.

Wei, M. 1997: Revision of the genus Caliroa O. Costa (Hymenoptera: Heterarthridae) from China. - Entomotaxonomia. Supplement. 19: 51-58.

Xiao, G.-r. 1993: Two new species of sawflies from China (Hymenoptera, Tenthredinidae). - Forest Research. 6: 618-620.

Zombori, L. 1977: New sawfly species from Korea (Hymenoptera: Symphyta). - Acta Zoologica Academiae Scientiarum Hungaricae. 24, 1-2: 253-268. 